\title{
Themes and Topics of Research in Marketing: A Content Analysis of the Articles Published in Three Marketing Journals
}

\author{
Mahmoud Abdel Hamid Saleh ${ }^{1}$ \\ ${ }^{1}$ Department of Marketing, College of Business Administration, King Saud University, Riyadh, Saudi Arabia \\ Correspondence: Mahmoud Abdel Hamid Saleh, Ph.D., Associate Professor of Marketing, Department of Marketing, \\ College of Business Administration, King Saud University, Riyadh, Saudi Arabia. Tel: 966-59-646-2433.
}

Received: November 24, 2015

doi:10.5430/ijba.v7n1p12
Accepted: December 8, $2015 \quad$ Online Published: January 4, 2016

URL: http://dx.doi.org/10.5430/ijba.v7n1p12

\begin{abstract}
This study aimed at classifying the themes of marketing in the articles published in three top journals in the field of marketing from 2010 to 2014. At the same time, the study aimed at identifying the researchers' interest and topics in each theme. The study findings demonstrated that the Journal of Marketing Research has got a share of 39\% of the total published articles of those three journals, compared to 35\% for the Marketing Science journal, and 26\% for the Journal of Marketing. With respect to the research themes, extensive interest has been given to consumer behavior at $22 \%$, e-marketing at $10 \%$, advertising at $7 \%$, promotion and pricing at $7 \%$ each, product development at $5 \%$, and marketing management at $4 \%$. The study also concluded the researchers' negligence of important themes in marketing theory, such as: marketing ethics, international marketing, social responsibility, service marketing, competitive analysis, and customer relationship management. Moreover, The study found that each of the three journals has extensively published on some specific themes compared to the other two journals. The journal of Marketing Science has published more articles on e-marketing, channels of distribution, competitive analysis, and marketing ethics. The Journal of Marketing has published more articles on branding, sales and sales management, value creation, services and service quality, customer relationship management, international marketing, social responsibility, and customer loyalty. The Journal of Marketing Research has published more articles on consumer behavior, branding, pricing, retailing, and customer satisfaction.
\end{abstract}

Keywords: marketing, research, themes, topics, content, analysis, articles, trend

\section{Introduction}

The trends of the research in marketing are changing with the change of business environment. Therefore, it is important to have a continuous overall content analysis of the published articles on marketing in order to know what is going on in research concerning the business world. This type of analysis enables marketing researchers to follow up the chain of development in marketing theory and practice, and the interrelationship between them. This sort of integration and generalization of marketing theory and empirical research, past and present, are considered the building blocks for marketing science (Bass \& Wind, 1995). Empirical generalizations in different themes are necessary to arrive at laws of marketing (Burgess and Steenkamp, 2006) and for future development as well. That is, as Weidmann et al. (2011) mentioned: “the more complex the marketer's world gets, the more we have to understand the underlying trends which mark the direction of future developments".

The present study focused on published articles in three of the highly-ranked journals in marketing, they are: Journal of Marketing Research, Marketing Science, and Journal of Marketing. The study is an extension of a previous research done by Haji-Basri (2012) who studied the marketing research contemporary themes and trends between 2000 and 2009 in the same three journals.

The current study is basically directed to academicians in the field of marketing. The main objective of this study is to investigate what the major themes of marketing were manipulated by the authors during the period 2010-2014. It gives academic researchers a view of what the unfortunate themes and topics in marketing are. This may stir the researchers' curiosity to do research on these neglected topics. The proportions of the themes at the journal level may also unveil the needed themes and topics for future research. 
Concisely, this study gives answers to questions regarding what is published in three highly ranked journals in the field of marketing. First, what are the main themes that the researchers have given interest to during the period from 2010 to 2014, and what are the proportions of them? Second, what are the comparative proportions of the marketing themes on the level of a marketing journal (horizontal analysis)? Third, What are the proportions of these themes on the level of each single journal (vertical analysis)? Fourth, what are the main topics that have been manipulated in each of the marketing themes?

\section{Previous Research}

In addition to the main reference of this study (Haji-Basri, 2012). Other researchers have followed the content analysis approach in analyzing the articles in marketing journals. Lehmann et al. (2011) has investigated the level of analytical rigor and relevance in the articles of four academic journals between 2005 and 2009. The investigated journals were: Journal of Marketing, Journal of Marketing Research, Journal of Consumer Research, and Marketing Science. The study concluded the overemphasis of rigor in research in marketing. Consequently, relevance, communicability, and simplicity characteristics have been downplayed.

Yadav (2010) analyzed the articles published over 30 years between 1987 and 2007 in four major marketing journals: Journal of Marketing Research, Journal of Consumer Research, Marketing Science, and Journal of the Academy of Marketing Science. Investigating the conceptual articles, The researcher has concluded that conceptual articles in marketing journals are declining as a whole.

Dahlstorm et al. (2008) investigated marketing articles that were published between the years 1986 and 1990, and the years between 1996 and 2000 in two journals in the field of marketing: Journal of Marketing and Journal of Marketing research. The study presented diversity as a procedure to examine the likelihood that research in marketing contributes to the theory and practice. It provided a conceptual framework of diversity among strategies, measures, and methods employed in marketing research.

Moreover, in a content analysis of 1,195 articles published in three prominent marketing journals between 1993 and 2002, Hanson and Grimmer (2007) found that $46.3 \%$ of the published articles have used quantitative research methods, while $24.8 \%$ employed qualitative research methods.

With respect to the themes of marketing, Yoo et al. (2011) investigated the hospitality marketing research between 2000 and 2008 in four hospitality Journals: Cornell Hospitality Quarterly, International Journal of Hospitality Management, Journal of Hospitality and Tourism research, and International Journal of Contemporary Hospitality Management. The findings revealed the researchers' interest of specific themes, they are: consumer behavior, market segmentation, targeting, positioning, marketing strategies, marketing management, marketing performance, pricing, revenue, and yield management.

On the same line, Line \& Runyan (2011) have reviewed the hospitality marketing research published in four top hospitality journal from 2008 to 2010 . The purpose of this review was to identify trends and gaps in the literature of hospitality marketing research. The article analyzed the previous research based on research topics, industry focus, and analysis techniques. The study findings demonstrated that the vast majority of recent marketing hospitality research is geared towards the function of marketing or its environment.

An analysis of 250 articles from three major journals (Marketing Science, Journal of Marketing, European Journal of Marketing) published between 2007 and 2009 identified 12 key marketing themes, they are: branding, retail and distribution, consumer behavior, marketing research, sales, Internet, marketing strategy, communication, customer satisfaction, product services, and others (Collesei et al., 2010).

Similarly, Haji-Basri (2012) has classified the marketing themes into 21 themes: consumer behavior, management and planning, pricing, marketing function and strategy, new product development, branding, electronic marketing and information technology, research methodology, theory and philosophy of science, advertising, sales (promotion/management), distribution, customer satisfaction; legal, political, and economic issues; ethics and scocal responsibility, services, loyalty, value creation, retailing, international and comperative.

\section{Methodology}

The study relied on three global highly-ranked journals of marketing which are: Journal of Marketing, Journal of Marketing Research, and Marketing Science. The investigated articles are that those have been published in the three journals between the years 2010 and 2014. 
The researcher has adopted the content analysis approach to investigate the themes and the topics of marketing in the selected marketing journals. In essence, the analysis has depended on the article title and abstract to identify the article topic and in which theme it should be included.

The marketing themes in this study has been classified into 22 themes which are near the classification of Haji-Basri (2012) with some modifications. The researcher browsed the articles one by one to identify two things: the topic of the article, and the theme in which to be included.

Accordingly, the researcher counted the frequencies of each theme in each journal, as well as identified the topics in each theme. Statistics are analyzed in 5 parts. First, the overall proportions of the journal's share of publications as well as in each theme. Second, the overall proportions of marketing themes in the three journals. Third, a comparative analysis of the marketing themes among the journals. Fourth, a vertical comparison of the themes on the level of each single journal. At the end, the researcher has set a table that included the main marketing topics of the articles in each theme. This is of high importance for the researchers to have a quick knowledge on the marketing topics that have been investigated as a base for research planning.

\section{Proportions of the Marketing Themes on a Theme Level}

Table (1) shows the proportions of articles on the three journals and of marketing themes that have been investigated between 2010 and 2014. The number of themes is 22 major themes. These themes reflect the researchers' specific interest in the field of marketing. The table shows the horizontal analysis on the theme level. Some important findings of this table are as follows:

a. Initially, the Journal of Marketing Research has got the highest share of the total articles that have been published between 2010 and 2014 at a percentage of 39\%, then, the journal of Marketing Science at 35\%, and the Journal of Marketing at $26 \%$.

b. Consumer behavior theme has got the highest proportion of researchers' interest, representing $22 \%$ of the marketing articles on all the marketing themes. On the journal level, the Journal of Marketing Research's share in this theme accounted for 55\%, while the journal of Marketing Science accounted for $23 \%$, and the Journal of Marketing accounted for $22 \%$. This reflects the researchers' interest in consumer behavior research. However, this is relatively normal if we take into account that consumer behavior research is a base for setting marketing program and strategies.

c. The articles published in the e-marketing theme accounted for $10 \%$ of all the published articles in the three journals. The Marketing Science journal has got the highest proportion which accounted for $58 \%$ of the published articles, while, it is accounted for $21 \%$ in each of the Journal of Marketing Research and the Journal of Marketing. This may reflect the interest of the Marketing Science journal to cope with the new wave in marketing compared to the other two journals.

d. Research on the advertising theme has got only $7 \%$ of all the articles published in the three marketing journals. The Journal of Marketing Research has had the highest proportion in this theme at $48 \%$ of the published articles, then comes journal of Marketing Science at 39\%, and the Journal of Marketing at 13\%. This may reflect the interests of the Journal of Marketing Research and Marketing Science journal to advertising theme compared to the other two journals.

e. Branding articles represented $7 \%$ of all the published articles in the three journals. This is really surprising, taking into account the role of branding both in marketing theory and successful marketing practices. The Journal of Marketing has had the highest share at 43\%, then, the Journal of Marketing Research at 35\%, and the journal of Marketing Science at $22 \%$.

f. The articles that investigated research methods in marketing accounted for $7 \%$ of published articles in the three journals. The Marketing Science journal has had the highest proportion of 58\% of the published articles, then comes the Journal of Marketing Research at $42 \%$. However, it seems that the Journal of Marketing does not pay too much attention of such a theme.

g. Promotion theme has been paid a relatively balanced attention among the three journals. The articles on this theme ranged between $31 \%$ and $35 \%$. Conversely, pricing theme has been paying more attention in both the Journal of Marketing Research and the journal of Marketing Science at $44 \%$ and $42 \%$ respectively. While it accounted for only $14 \%$ in the Journal of Marketing.

h. It could be noted that Some themes represented weak proportions such as: marketing ethics, customer loyalty, social responsibility, international marketing, customer relationship management, services and 
service quality. Each of these themes has got a share of $1 \%$ only. Other themes have got a little better share of $2 \%$ per each, they are: Sales and salesmanship, retailing, channels of distribution, value creation, and customer satisfaction. The weak representation of all these themes could be attributed to the previous research that has been extensively done on them for decades ago.

i. Generally, each of the three journals has extensively published articles on some specific themes compared to the other two journals. The journal of Marketing Science has published more articles in e-marketing, channels of distribution, competitive analysis, and marketing ethics. The Journal of marketing has published more articles on branding, sales and sales management, value creation, services and service quality, customer relationship management, international marketing, social responsibility, and customer loyalty. The Journal of Marketing Research has published more articles on consumer behavior, branding, pricing, retailing, and customer satisfaction.

Table 1. Overall proportions of marketing themes (Horizontal analysis on the theme level)

\begin{tabular}{llcccc}
\hline Ser. & \multicolumn{1}{c}{ Themes } & $\begin{array}{c}\text { Marketing } \\
\text { Science }\end{array}$ & $\begin{array}{c}\text { Journal of } \\
\text { Marketing }\end{array}$ & $\begin{array}{c}\text { Journal of } \\
\text { Marketing } \\
\text { research }\end{array}$ & Total \\
\hline 1 & Consumer behavior & $23 \%$ & $22 \%$ & $55 \%$ & $22 \%$ \\
2 & e-marketing & $58 \%$ & $21 \%$ & $21 \%$ & $10 \%$ \\
3 & Advertising & $39 \%$ & $13 \%$ & $48 \%$ & $7 \%$ \\
4 & Branding & $22 \%$ & $43 \%$ & $35 \%$ & $7 \%$ \\
5 & Research methods & $58 \%$ & $0 \%$ & $42 \%$ & $7 \%$ \\
6 & Promotion & $33 \%$ & $31 \%$ & $35 \%$ & $7 \%$ \\
7 & Pricing & $42 \%$ & $14 \%$ & $44 \%$ & $7 \%$ \\
8 & Product development & $38 \%$ & $25 \%$ & $38 \%$ & $5 \%$ \\
9 & Marketing management & $30 \%$ & $33 \%$ & $37 \%$ & $4 \%$ \\
10 & Sales and sales management & $17 \%$ & $44 \%$ & $39 \%$ & $2 \%$ \\
11 & Retailing & $33 \%$ & $22 \%$ & $44 \%$ & $2 \%$ \\
12 & Channels of distribution & $50 \%$ & $31 \%$ & $19 \%$ & $2 \%$ \\
13 & Value creation & $25 \%$ & $50 \%$ & $25 \%$ & $2 \%$ \\
14 & Customer satisfaction & $29 \%$ & $29 \%$ & $43 \%$ & $2 \%$ \\
15 & Services and service quality & $18 \%$ & $64 \%$ & $18 \%$ & $1 \%$ \\
16 & Competitive analysis & $91 \%$ & $0 \%$ & $9 \%$ & $1 \%$ \\
17 & Customer relationship & $10 \%$ & $90 \%$ & $0 \%$ & $1 \%$ \\
18 & International marketing & $11 \%$ & $56 \%$ & $33 \%$ & $1 \%$ \\
19 & Social responsibility & $0 \%$ & $75 \%$ & $25 \%$ & $1 \%$ \\
20 & Customer loyalty & $17 \%$ & $50 \%$ & $33 \%$ & $1 \%$ \\
21 & Marketing ethics & $50 \%$ & $25 \%$ & $25 \%$ & $1 \%$ \\
22 & Others & $30 \%$ & $35 \%$ & $35 \%$ & $6 \%$ \\
& Total & $35 \%$ & $26 \%$ & $39 \%$ & $100 \%$ \\
\hline
\end{tabular}

\section{Proportions of the Marketing Themes on a Journal Level}

Table (2) shows marketing themes of the published articles in each of the three marketing journals. The table was analyzed vertically to make a type of comparison among the proportions in each journal to present the relative importance of the marketing themes. The main findings of this analysis are as follows:

a. e-marketing articles represented the highest relative importance theme of the Marketing Science journal at 17\%, then consumer behavior at $15 \%$, research methods at $12 \%$, advertising at $8 \%$, and pricing at $8 \%$. Those five themes represented about $60 \%$ of all articles in the 22 themes in this journal. Some themes represented a weak 
proportion such as: marketing ethics, customer loyalty, social responsibility, international marketing, customer relationship management, services, and service quality.

b. Consumer behavior articles represented the highest relative importance theme in Journal of Marketing at $18 \%$, then branding at $11 \%$, e-marketing at $8 \%$, promotion at $8 \%$, product development at $5 \%$, and customer relationship management at $4 \%$. Those six themes represented about $55 \%$ of all articles in the 22 themes in the journal. Some themes represented weak proportions such as: marketing ethics, competitive analysis, research methods, and customer loyalty. But, the Journal of marketing seems relatively balanced in themes proportions compared with the other two journals.

c. Consumer behavior articles represented the highest relative importance theme in Journal of Marketing Research at $32 \%$, then advertising at $9 \%$, research methods at $7 \%$, pricing at $7 \%$, branding at $6 \%$, promotion at $6 \%$, e-marketing at $5 \%$, and product development at $5 \%$. Those eight themes represented about $77 \%$ of articles in all the 22 themes. Some themes represented weak proportions in this journal such as: marketing ethics, social responsibility, customer loyalty, international marketing, customer relationship management, competitive analysis, service and service quality, value creation, and channels of distribution.

Table 2. Overall proportions of marketing themes (Vertical analysis on the journal level)

\begin{tabular}{llccc}
\hline Ser. & \multicolumn{1}{c}{ Themes } & $\begin{array}{c}\text { Marketing } \\
\text { Science }\end{array}$ & $\begin{array}{c}\text { Journal of } \\
\text { Marketing }\end{array}$ & $\begin{array}{c}\text { Journal of } \\
\text { Marketing } \\
\text { research }\end{array}$ \\
\hline 1 & Consumer behavior & $15 \%$ & $18 \%$ & $32 \%$ \\
2 & e-marketing & $17 \%$ & $8 \%$ & $5 \%$ \\
3 & Advertising & $8 \%$ & $3 \%$ & $9 \%$ \\
4 & Branding & $5 \%$ & $11 \%$ & $6 \%$ \\
5 & Research methods & $12 \%$ & $0 \%$ & $7 \%$ \\
6 & Promotion & $6 \%$ & $8 \%$ & $6 \%$ \\
7 & Pricing & $8 \%$ & $3 \%$ & $7 \%$ \\
8 & Product development & $6 \%$ & $5 \%$ & $5 \%$ \\
9 & Marketing management & $3 \%$ & $4 \%$ & $3 \%$ \\
10 & Sales and sales management & $1 \%$ & $4 \%$ & $2 \%$ \\
11 & Retailing & $2 \%$ & $2 \%$ & $3 \%$ \\
12 & Channels of distribution & $3 \%$ & $2 \%$ & $1 \%$ \\
13 & Value creation & $2 \%$ & $4 \%$ & $1 \%$ \\
14 & Customer satisfaction & $2 \%$ & $2 \%$ & $2 \%$ \\
15 & Services and service quality & $1 \%$ & $3 \%$ & $1 \%$ \\
16 & Competitive analysis & $4 \%$ & $0 \%$ & $0 \%$ \\
17 & Customer relationship management & $0 \%$ & $4 \%$ & $0 \%$ \\
18 & International marketing & $0 \%$ & $2 \%$ & $1 \%$ \\
19 & Social responsibility & $0 \%$ & $3 \%$ & $1 \%$ \\
20 & Customer loyalty & $0 \%$ & $1 \%$ & $1 \%$ \\
21 & Marketing ethics & $1 \%$ & $0 \%$ & $0 \%$ \\
22 & Others & $5 \%$ & $8 \%$ & $5 \%$ \\
& & $100 \%$ & $100 \%$ & $100 \%$ \\
\hline & & & & \\
\hline
\end{tabular}

\section{Topics of Marketing in Each Theme}

Table (3) shows the main topics that were manipulated in each marketing theme in the published articles in the three marketing journals between 2010 and 2014. The table shows a diversity of topics the researchers manipulated in each theme. Extensive research has been done in some themes, especially in consumer behavior, e-marketing, advertising, research methods, and product development. 
Table 3. Research topics in marketing themes

\begin{tabular}{|c|c|c|}
\hline Ser & Themes & Topics \\
\hline 1 & $\begin{array}{l}\text { Consumer } \\
\text { behavior }\end{array}$ & $\begin{array}{l}\text { Consumer rate of saturation - willingness to pay - choice and decision process - activity } \\
\text { consumption - customer preferences - effect of negative emotion - complaining behavior - } \\
\text { post-purchase consumption - discrimination consumers - saving behavior - perceived velocity } \\
\text { - effect of credit card on spending - consumer's trust - consumer's relaxation and monetary } \\
\text { evaluation of the products - effect of word-of-mouth - consumer learning and switching cost - } \\
\text { influence of fiends in consumer spending - consumer responsiveness to peer recommendations } \\
\text { - consumer imagination - multiattributre preferences - portion size and consumption - } \\
\text { Consumer adoption of new products - effect of samples on choice - consumer's taste } \\
\text { perceptions- customer's package size impressions - ethnography and market learning - social } \\
\text { influence on product rating - post purchase regret - older consumers buy older brands - } \\
\text { consumer learning - consumer's death - brand switching - customer community participation - } \\
\text { observational learning. }\end{array}$ \\
\hline 2 & e-marketing & $\begin{array}{l}\text { Online word-of-mouth }- \text { banner advertising }- \text { online freelance marketplace }- \text { choice } \\
\text { interdependence on social networks }- \text { online point-of-purchase behavior }- \text { online display } \\
\text { advertising }- \text { image related utility in social media }- \text { social media marketing }- \text { online product } \\
\text { opinions }- \text { online user generated content }- \text { digital rights management }- \text { google search } \\
\text { advertising }- \text { online auctions }- \text { digital distribution }- \text { online user review }- \text { Internet media } \\
\text { selection -viral marketing - online retailers -online agents }- \text { digital channels }- \text { word-of-mouth } \\
\text { marketing - multiple relationships in social networks - online product rating forums - online } \\
\text { social interactions - mapping online customer search - search on the Internet - online retailers. }\end{array}$ \\
\hline 3 & Adve & $\begin{array}{l}\text { Marketing orientation in advertising - online advertising - advertising and consumer awareness } \\
\text { - how advertising grows sales - dynamic effectiveness of advertising - deceptive advertising - } \\
\text { fear appeals in advertising - video advertisement - advertising budgets - online advertising } \\
\text { markets - advertising strategies - recognition tests in advertising - informative advertising - } \\
\text { consumer generated ads - consumer advertising - advertising in presidential elections - } \\
\text { uninformative advertising - paid search advertising. }\end{array}$ \\
\hline 4 & Branc & $\begin{array}{l}\text { Store brands - brand extension - optimal branding - brand positioning - brand licensing - brand } \\
\text { anthropomorphization - brand attitudes - foreign brand - brand equity - brand concepts - brand } \\
\text { love - brand acquisition - brand personality - copycat brands - brand rating - brand satiation - } \\
\text { consumption based cross-brand learning - alphanumeric brand names - brand dilution. }\end{array}$ \\
\hline 5 & $\begin{array}{l}\text { Research } \\
\text { methods }\end{array}$ & $\begin{array}{l}\text { Improving preauch diffusion forcasts: using synthetic networks as stimulated priors - fussing } \\
\text { aggregate and dis aggregate data with an application to multiplatform media consumption - } \\
\text { spotlights, floodlights, and the magic number zero: simple effects test in moderated regression - } \\
\text { quantitative trendspotting - misresponse to reversed and negated items in surveys - complexity } \\
\text { effects in choice experiment-based model - respond subistitution in consumer surveys - } \\
\text { measurement of consumer's willingness to pay - cumulative timed intent: new predictive tol for } \\
\text { technology adotion - mindset metrics in market response model - structural equation modeling } \\
\text { - analysing moment-to-moment using Bayesian functional linear model - model selection using } \\
\text { database charactersitics - multactivity latent attrition model for customer base analysis - } \\
\text { methods from sampling responses from large scale quantitative data - Copual modeling of } \\
\text { marketing data. }\end{array}$ \\
\hline 6 & Promotion & $\begin{array}{l}\text { Competitive promotional strategies - celebrity endorsement }- \text { word-of- mouth generation - } \\
\text { online communications - negative publicity - free-product samples - trade promotions - } \\
\text { customer referral programs - shelf displays - multichannel communication - price promotion - } \\
\text { consumer communication - contest design - sample experiential - products - sales promotion - } \\
\text { reference group messages - discount pricing promotion. }\end{array}$ \\
\hline 7 & Pricing & $\begin{array}{l}\text { Price elasticity - pricing strategy - reference price - price presentation - price estimation - price } \\
\text { completion - price discounts - price framing - competitive non-linear pricing - dynamics of } \\
\text { pricing - price fairness - price image - multicomponent-systems pricing - pricing of used goods } \\
\text { - uniform price - quality discounts - pricing multistage customized online bundles - optimal } \\
\text { reverse pricing mechanism - price promotion - retail pricing - price precision. }\end{array}$ \\
\hline
\end{tabular}


$8 \quad$ Product $\quad$ Strategies for innovation - cocreation - product line design - new product introduction - new development product preannouncement - technological innovation - labeling - new product diffusion private labels - consumer's innovation perceptions - product development team - new product development stages - sales person influence on product development - raw ideas in innovation - diffusion of consumer packaged goods - forecasting marketing-mix responsiveness for new products - new product introduction.

9 Marketing Demarketing to manage customer quality inferences - implementing changes in marketing management strategy - competition in status goods market - model-based segmentation - dynamic marketing budgeting - aggressive marketing strategy - targeting revenue leaders - usage of marketing metrics.

10 Sales and $\quad$ Bonuses versus commissions - reciprocity - cross-selling - sales force compensation - personal sales $\quad$ selling elasticities - effect of marketing strategy on brand sales - sales team performance - sales management reps follow ups - levels of sales person customer orientation - motivating sales people energizing reseller's sales force - bonus and sales productivity.

11 Retailing Wal-Mart's impact on supplier profits - online retailing - service allocations - retail chain impact of Wal-Mart on incumbent retailers reactions and their sales outcomes - store remodeling - retail category management - optimizing retail assortments - retailer shelf layout - retail driven product bundle.

\begin{tabular}{|c|c|c|}
\hline 12 & $\begin{array}{l}\text { Channels of } \\
\text { distribution }\end{array}$ & $\begin{array}{l}\text { Punishment in distribution network - partially integrated channel - customer channel choice - } \\
\text { perceived unfairness of channels of distribution - distributor's changing motivation - } \\
\text { information acquisition and sharing in vertical relationship. }\end{array}$ \\
\hline 13 & $\begin{array}{l}\text { Value } \\
\text { creation }\end{array}$ & $\begin{array}{l}\text { Unintended value - effect of chief marketing officer on firm value - queuing and value of } \\
\text { products - customer value maximizing sweepstake and contests - value creation through major } \\
\text { channel expansions - creating major innovativeness with customers - customer participation in } \\
\text { value creation - value creation and profits - exclusive channels. }\end{array}$ \\
\hline 14 & $\begin{array}{l}\text { Customer } \\
\text { satisfaction }\end{array}$ & $\begin{array}{l}\text { Customer satisfaction and firm value - shapping customer satisfaction through self-awareness } \\
\text { cuses - customer satisfaction heterogeneity and shareholder value - impact of feature } \\
\text { alignability on satisfaction - effects of customer satisfaction on customer spending - customer } \\
\text { satisfaction effects on domestic product purchase - customer satisfaction and repurchase link - } \\
\text { customer satisfaction survey responses - satisfying choice model - strategic influence of } \\
\text { customer satisfaction. }\end{array}$ \\
\hline 15 & $\begin{array}{l}\text { Services and } \\
\text { service } \\
\text { quality }\end{array}$ & $\begin{array}{l}\text { Service innovativeness - optimizing service productivity - can stressed employees deliver better } \\
\text { customer service - service revolution. }\end{array}$ \\
\hline 16 & $\begin{array}{l}\text { Competitive } \\
\text { analysis }\end{array}$ & $\begin{array}{l}\text { Competition and its impact on paid-search advertising - supplier competition - downstream } \\
\text { competition - competition in customer shopping experience - competing for low-end-markets - } \\
\text { retail competition. }\end{array}$ \\
\hline 17 & $\begin{array}{l}\text { Customer } \\
\text { relationship } \\
\text { management }\end{array}$ & Customer management dilemma - relationship velocity - customer portfolio. \\
\hline 18 & $\begin{array}{l}\text { International } \\
\text { marketing }\end{array}$ & $\begin{array}{l}\text { Conflict management in franchise relationships - marketing channels in foreign markets - ex } \\
\text { post behavior in franchise channel relationship - foreign marketing adaptation - international } \\
\text { marketing alliances - marketing budget allocations across countries. }\end{array}$ \\
\hline 19 & $\begin{array}{l}\text { Social } \\
\text { responsibility }\end{array}$ & Social responsibility - corporate social responsibility - sustainability reliability. \\
\hline 20 & $\begin{array}{l}\text { Customer } \\
\text { loyalty }\end{array}$ & Customer loyalty - item-based loyalty program - store loyalty - brand switching. \\
\hline 21 & $\begin{array}{l}\text { Marketing } \\
\text { ethics }\end{array}$ & Customer bill of rights - unhealthy food - products with ethical attributes - healthy eating. \\
\hline 22 & Others & $\begin{array}{l}\text { vulatory cycle - return migration performances - disfluency signals - procurement auctions - } \\
\text { iff structure - saving behavior - data-based decision making. }\end{array}$ \\
\hline
\end{tabular}




\section{Findings and Conclusions}

a. There was a high interest from researchers in some few themes of the research in marketing such as: consumer behavior, e-marketing, promotion, and pricing. This may be normal, taking into account that the consumer behavior research is a base of setting marketing strategies that match the consumer's decision making process and the factors that influence his/her decisions. The e-marketing's worldwide orientation is still a new strategy in contemporary marketing that attracts the curiosity of researchers to give more concern to its related topics. Additionally, themes of promotion and advertising are cornerstones in any marketing programs, and researchers will not stop investigating them.

b. Researchers did not give much concern to some important themes in marketing, including: marketing ethics, social responsibility, international marketing, competitive analysis, service activities, and quality of service, in spite of the importance of these themes in the contemporary marketing theory, especially in the fields of consumer protection, social roles of Businesses, international trade relations, the business wars, and the service sector all over the world.

c. Research interests for each journal are different from the other. It seems that the Journal of Marketing Research gave high priority to studies on consumer behavior, while the Marketing Science journal gave its highest research priority to e-marketing. On the other hand, there was a relative balance in the marketing themes of research interests in the Journal of Marketing; as there is a more balanced distribution of the research themes compared to the other two journals.

d. The focus of marketing journals on specific marketing themes may encourage the researches to do research on those themes and neglect others. The journals might make some balance among the different, but integrated, marketing themes. Hence, the research themes could be done up to the researchers' interests as long as they are related to the marketing theory and practice.

\section{Limitations}

Classifying the article topic on the selected major themes of the research is just a personal judgement of the researcher who tried - as possible - to focus on the main topic of the article to avoid the interrelationship of each article topic with different themes.

\section{References}

Bass, F. M., \& Wind, J. (1995). Introduction to special issue: Empirical generalizations in marketing. Marketing Science, 14, 1-5. http://dx.doi.org/10.1287/mksc.14.3.G1

Burgess, S. M., \& Steenkamp, J.-B. (2006). Marketing renaissance: how research in emerging markets advances marketing science and practice. International Journal of Research in Marketing, 23, 337-356. http://dx.doi.org/10.1016/j.jiresmar.2006.08.001

Collesei, U., Andreani, J., Conchon, F., Halliburton, C., Koshy, A., Lu, T., ... Wiedmann, K. (2010). Marketing trends: Toward new research perspectives. Journal of Marketing trends, 1(2), 5-6. Retrieved from http://www.marketing-trends-congress.com/sites/default/files/Edito_0.pdf

Dahlstorm, R., Nygaard, A., \& Crosno, J. (2008). Strategic, metric, and methodological trends in marketing research and their implications. Journal of Marketing Theory and Practice, 16(2), 139-152. http://dx.doi.org/10.2753/MTP1069-6679160204

Haji-Basri, M. (2012). Marketing research contemporary themes and trends. Interdisciplinary Journal of Contemporary Research in Business, 4(5), 17-24. Retrieved from http://journal-archieves23.webs.com/17-24.pdf

Hanson, D., \& Grimmer, M. (2007). The mix of qualitative and quantitative research in major marketing journals, 1993-2002. European Journal of Marketing, 41(1/2), 58-70. http://dx.doi.org/10.1108/03090560710718111

Lehman, D. R., McAlister, L., \& Staelin, R. (2011, July). Sophistication in research in marketing. Journal of Marketing, 75, 155-165. http://dx.doi.org/10.1509/jmkg.75.4.155

Line, N. D., \& Runyan, R. C. (2012). Hospitality marketing research: recent trends and future directions. International Journal of Hospitality Management, 31, 477-488. http://dx.doi.org/10.1016/j.ijhm.2011.07.006

Weidmann, K., Andreani, J., Collesei, U., Conchon, F., Halliburton, C., Koshy, A., ...Vescovi, T. (2011). Marketing trends: the research process. Journal of Marketing trends, 1(5), 5-6. Retrieved from http://www.marketing-trends-congress.com/sites/default/files/Edito_2.pdf

Yadav, M. S. (2010). The decline of conceptual articles and implications for knowledge development. Journal of Marketing Research, 74(1), 1-19. http://dx.doi.org/10.1509/jmkg.74.1.1

Yoo, M., Lee, S., \& Bai, B. (2011). Hospitality marketing research from 2000 to 2009: topics, methods and trends. International Journal of Contemporary Hospitality Management, 23(4), 517-532. http://dx.doi.org/10.1108/09596111111130010 